\title{
Regional Traffic \& Medical Services and Cost Efficiency of International Tourist Hotels in Taiwan
}

\author{
Jin-Li Hu ${ }^{1}$, Fang-Yu Yeh ${ }^{2} \&$ Yun-Chih Tsai ${ }^{1}$ \\ ${ }^{1}$ Institute of Business and Management, National Chiao Tung University, Taiwan \\ ${ }^{2}$ Science \& Technology Policy Research and Information Center, National Applied Research Laboratories, \\ Taiwan \\ Correspondence: Jin-Li Hu, Institute of Business and Management, National Chiao Tung University, Taiwan. Tel: \\ 02-23-812-386 ext. 57641. E-mail: jinlihu@ gmail.com
}

Received: August 3, 2014

Accepted: September 2, 2014

Online Published: September 25, 2014

doi:10.5539/ibr.v7n10p36

URL: http://dx.doi.org/10.5539/ibr.v7n10p36

\begin{abstract}
This study analyzes how regional public transport facilities and medical services affect the efficiency of international tourist hotels (ITHs). First, we adopt data envelopment analysis (DEA) to measure the cost efficiency of international tourist hotels in Taiwan during 1998 to 2009. Next, we use the truncated regression to estimate the effect of traffic convenience and medical services on cost efficiency. The distance to international airports and distance to MRT station have significantly negative effects on cost efficiency of international tourist hotels, while the distance to the freeway exit, distance to bus station, and pick-up service, chain system, and shorter operating year have significantly positive impacts on their cost efficiency. The shorter distance to the hospital and more hospitals in a region significantly improve cost efficiency of ITHs in Taiwan.
\end{abstract}

Keywords: international tourist hotels, cost efficiency, travel convenience, medical services

\section{Introduction}

The demand for travelling has been increasing rapidly along with the economic growth and the dramatically improved quality of life. In recent years, tourism not only has become the main source of foreign exchange earnings, but also plays an indispensable role in economic development in most countries. The tourism industry is also one of the six emerging industries in Taiwan, and many strategies are developed to attract tourists in recent years. With the active promotion of the tourism industry by the Taiwanese Government, it has become more and more important in the economic development. Between 2005 and 2009, revenue of the tourism industry has increased by $4.5 \%$, from $1.98 \%$ to $2.07 \%$ of GDP, and the number of employment has also increased by $32.8 \%$, from 205,000 to 273,000 people (Chou et al., 2011).

According to the statistical results of the Taiwan Tourism Bureau, most tourists chose to lodge in the hotels, and they spent $39.32 \%$ of their total traveling expenditures in hotels (Chou et al., 2011). Tourists spent NT\$ 165 billion dollars in the international tourist hotels (ITHs), which accounts for $62.12 \%$ among the total accommodation expenditures (Chou et al., 2011). Thus, international tourist hotel industry is one of the key successful sectors of the tourism industry. Since 1987, Taiwanese government has gradually removed the constraints in the Regulation for the Management of Tourist Hotel Enterprises; consequently the number of international tourist hotels in Taiwan has risen from 44 in 1985 to 70 in 2010, meanwhile becoming more competitive. In order to survive and gain profits, efficiency is an essential factor to be considered when developing strategies. Efficiency measurement can help the hotel managers control idle resources in the operating process as well as improve the allocation of resources, and it also enables the hotels to find their own strengths and weaknesses by comparing with the performance of the whole industry (Chen, 2007; Honma and $\mathrm{Hu}, 2012$ ). Consequently, it is important to evaluate the efficiency appropriately and to utilize the factors which can improve the efficiency.

Transportation is the key factor for tourists to visit each tourist attraction, and it is also essential in tourism activities. A well-developed infrastructure for transportation is an important factor for tourists to choose and reach their destinations, and it is also one of the basic requirements for the development of tourism (Akama \& Kieti, 2003). In addition, people may get sick or injured by accidents while travelling. If the patient could not 
receive immediate and appropriate medical treatment, then the degree of traveling risk shall increase and it will reduce the tourists' willingness to visit this destination again. Therefore, we want to analyze the effect of traffic convenience and medical services on the cost efficiency of hotels.

In this study, the cost efficiency of international tourist hotels in Taiwan during 1998-2009 is analyzed with a two-stage procedure. In the first stage, we adopt data envelopment analysis (DEA) to compute and rank the hotels according to their efficiency. In the second stage, we use the truncated regression suggested by Simar and Wilson (2007) to find out the effects of environmental variables (i.e., traffic convenience and regional medical services) on cost efficiency scores. We hope to assist the hotel manager, the hotel investor and the government to improve the hotel efficiency through the perspectives of transportation and public medical services.

The structure of this study is as follows: Section 2 gives a literature review on hotel efficiency and the interactive relations of traffic convenience and public medical services to tourism. Section 3 introduces the methodology and the data. Section 4 discusses the empirical results, and the conclusion is located in Section 5.

\section{Literature Review}

\subsection{Hotel Efficiency}

The concept of using frontier production function to measure efficiency is proposed by Farrell (1957), and he is the first one to divide cost efficiency into technical efficiency and allocative efficiency. Recently, there are more and more cases of study using the frontier approach to measure hotel performance, and DEA and SFA are two primary methods available to be found.

Anderson et al. (1999) use SFA to analyze the operating efficiency of 48 hotels in U.S.A. The input variables include the number of full-time equivalent employees, the number of rooms, total gaming related expenses, total food and beverage expenses and other expenses, while the output variables include the total revenues of rooms, gamming, food and beverage and other revenues. The results show that the average efficiency value of these hotels is $89.4 \%$, which is comparatively higher and in consistent with the condition of a highly efficient and competitive market.

Barros and Mascarenhas (2005) analyze the efficiency of 43 Portuguese state-owned hotels by DEA. The input variables include the number of full-time equivalent employees, the book value of the premises, and the number of rooms, while the output variables include sales, the number of guests, and the aggregated number of nights spent. The results show that there are only four hotels achieving technical efficiency and allocative efficiency, and the hotels close to main tourist routes or with more rooms receive higher efficiency scores. Organizational management environments with accountability, transparency and efficiency incentives may also improve the hotel performance.

Barros and Dieke (2008) use revenue per room as the output variable, and they use total cost and investment expenditure as the input variables to analyze the technical efficiency of 12 Luanda hotels by DEA. Their study finds that the efficiency of these hotels may increase during the observation period, but at a decreasing rate. In addition, market share and joint members of a group may also positively affect the efficiency of these hotels.

There are also some researchers studying the efficiency of hotels in Taiwan. Tsaur (2001) investigate 53 international tourist hotels in Taiwan from 1996 to 1998 by DEA under 7 input and 6 output variables. The average operating efficiency is $87.33 \%$, and the efficiency score for the catering divisions $(89.05 \%)$ is better than that of the room divisions $(71.3 \%)$. The hotels in chain operation are more efficient than others.

Hwang and Chang (2003) adopt DEA and the Malmquist method to measure the managerial performance of 45 international tourist hotels in Taiwan and the change of efficiency from 1994 to 1998. The result reveals that the efficiency of each hotel is significantly different according to its sources of customers and management styles. The study categorizes the hotel industries into six groups, based on efficiency and the change of efficiency, and suggests that the hotel managers can make strategies according to the characteristics of each group.

Chen (2007) studies the operating performance of 55 international tourist hotels by SFA and finds that the average efficiency is $80.3 \%$. The highest efficiency score is $97.72 \%$, and the lowest is $34.34 \%$. A comparison between the efficiency of chain and non-chain hotels indicates that the former is better than the latter.

$\mathrm{Hu}$ et al. (2009) use two-stage DEA to compute and explain the cost efficiency of international tourist hotels in Taiwan. The input variables include the number of rooms, the number of employees, and total floor space of catering division, while the output variables include total revenues of food and beverages, total revenues of rooms, and other revenues. The result shows that the average cost efficiency is $57 \%$, and the cost inefficiency is due in large part to technical inefficiency. The hotels in chain systems, located in resort areas, with a higher 
occupancy rate or near the international airports show significantly higher efficiency scores.

Chen et al. (2010) also employ DEA to measure the cost efficiency of international tourist hotels from 1997 to 2007 by using three input variables and three output variables. The research use Tobit regression in the second stage to analyze the effects of tourist nationalities on the cost efficiency of hotels.

Assaf et al. (2010) apply meta-frontier with four input variables and five output variables to analyze 78 international tourist hotels in Taiwan. They separate hotels into groups by size, ownership and classification. The result shows that the chain hotels, the larger hotels, and the international tourist hotels have higher efficiency scores.

\subsection{Traffic Convenience and Medical Services}

There are plenty of studies indicating that the development of transportation has deep connection with tourism industry. Khadaroo and Seetanah (2008) prove that transport infrastructure is an important factor in improving the international tourism flows. Prideaux (2000) outlines a transport cost model that identifies the significance of transport as a factor in destination development as well as in the selection of destinations by tourists. Transportation is also a key factor in the hotel industry, especially for the new investor and the travelers. Chou et al. (2008) probe into the indicators considered by investors in evaluating the location selection of hotels, showing that easy access to tourist attractions from hotel is an important factor. The convenience of location and parking are also two important factors for customers when choosing hotels (Saleh \& Ryan, 1992).

This study measures from an economic perspective of the traffic convenience of hotels and tries to apply the concept of the travel cost method (TCM), which is widely used to estimate the value of non-market goods, to the hotel efficiency research. The traditional TCM model estimates the number of trips as a demand function by using the cost of traveling to the site (Loomis et al., 2000). However, the number of trips is underestimated because it did not consider traveling time in the traditional method. Brown and Nawas (1973) construct a travel cost model including transportation cost, time cost and access cost, and Earnhahrt (2004) further proves that transportation cost and time cost have a significantly negative effect on recreational demand.

Prideux (2000) points out that the distance travelled is a key factor in determining the importance of transportation cost when selecting a destination because it includes both the actual fare cost and the time element. Shieh et al. (2014) find that generally most tourists in Taiwan prefer a larger, older, and closer-to-airport hotel. We use the distance between each international tourist hotels and each public transport facility to represent transportation cost. The shorter distance from public transport facilities to hotels, the less transport cost spent, making it more convenient to access. We want to study in details whether traffic convenience would affect the efficiency of hotels, and what kind of public transport facilities would help improve the efficiency of their nearby hotels.

Medical concern is one of the major risk factors by tourists before traveling (Carter, 1998; Lepp \& Gibson, 2003). International travelers may encounter the risks of receiving physical or psychological illness due of weather and hygiene problems, and the risks will be higher if countries visited provide inadequate medical services (World Health Organization, 2011). Tsaur et al. (1997) further demonstrated that medical support is also an important factor in evaluating health risks.

Public medical service is also a factor affecting tourists' decisions when choosing destinations. According to the previous investigations, sufficient public medical services have a positive impact on tourism development (Gauci et al., 2002). Batabyal \& Ghosh (2012) also point that the development of medical sector may significantly increase in tourist arrivals. The result of Yang et al. (2010) is similar to other studies. They analyze the cases of tourist arrivals in China and find that sufficient public health care is helpful in attracting international tourists. In this study, we are also concerned about whether medical resources would influence the cost efficiency of hotels.

There are plenty of studies in hotel efficiency, and we summarize them in Table 1. We find that type (Tsaur, 2001; Hwang \& Chang, 2003; Chen, 2007; Barros \& Dieke, 2008; Hu et al., 2009, 2010; Chen et al., 2010; Assaf et al., 2010), location (Hwang \& Chang, 2003; Barros \& Mascarenhas, 2005; Chen, 2007; Hu et al., 2009; Hu et al., 2010), scale (Barros \& Mascarenhas, 2005; Assaf et al., 2010), and the distance to the international airport (Hu et al., 2009; Chen, 2010; Shieh et al. 2014) are four variables used mostly in the existing literature for explaining the hotel efficiency. In the above literature, distance to an international airport is the only variable which is related to transportation. Since there is a strong relationship between traffic convenience and the hotel industry, we try to apply the concept of transportation cost to the research in hotel efficiency by using also other traffic-related variables, for example, the distances between public transport facilities and hotels. Public medical services are also an important concern in international travel, but there is currently lacking in any study which 
discusses the effect of medical services to hotel efficiency. We believe that more medical resources available for a hotel, the higher efficiency scores it would get. This is a new idea in the hotel industry. Overall, this study aims to focus on the issue that which kind of public transportation facilities will help improve the efficiency scores of their nearby hotels, and the actual effects of medical services on the hotel efficiency.

Table 1. Literature on hotel efficiency

\begin{tabular}{|c|c|c|c|}
\hline Authors & Method & Unit & Main findings \\
\hline $\begin{array}{l}\text { Anderson et al. } \\
\text { (1999) }\end{array}$ & SFA & $\begin{array}{l}48 \text { America } \\
\text { hotels, } 1994\end{array}$ & $\begin{array}{l}\text { The average efficiency score is } 89.4 \% \text {, and it's consistent with a highly } \\
\text { efficient and competitive market. }\end{array}$ \\
\hline $\begin{array}{l}\text { Barros \& } \\
\text { Mascarenhas (2005) }\end{array}$ & DEA & $\begin{array}{l}43 \text { Portuguese } \\
\text { hotels, } 2001\end{array}$ & $\begin{array}{l}\text { Scale economies, organizational governance environmental and location } \\
\text { affect the efficiency of hotels. }\end{array}$ \\
\hline $\begin{array}{l}\text { Barros \& Dieke } \\
(2008)\end{array}$ & DEA & $\begin{array}{l}12 \text { Luanda hotels, } \\
2000-2006\end{array}$ & $\begin{array}{l}\text { The efficiency score increase over the studied period. } \\
\text { Greater market share and network management can improve the efficiency. }\end{array}$ \\
\hline Tsaur (2001) & DEA & $\begin{array}{l}53 \text { Taiwan hotels, } \\
1996-1998\end{array}$ & $\begin{array}{l}\text { The average efficiency is } 87.33 \% \text {. } \\
\text { The chain-hotels have higher efficiency scores. }\end{array}$ \\
\hline $\begin{array}{l}\text { Hwang \& Chang } \\
\text { (2003) }\end{array}$ & DEA & $\begin{array}{l}45 \text { Taiwan hotels, } \\
\text { 1994-1998 }\end{array}$ & $\begin{array}{l}\text { The average efficiency is } 79.16 \% \text {. } \\
\text { The resort hotels and the international chain hotels have better performance. }\end{array}$ \\
\hline Chen (2007) & SFA & $\begin{array}{l}55 \text { Taiwan hotels, } \\
2002\end{array}$ & $\begin{array}{l}\text { The average efficiency is } 80.3 \% \text {. } \\
\text { The hotels of chain operation and the hotels located in resort area are more } \\
\text { efficient. }\end{array}$ \\
\hline Hu et al. (2009) & DEA & $\begin{array}{l}66 \text { Taiwan hotels, } \\
1997-2006\end{array}$ & $\begin{array}{l}\text { The average cost efficiency is } 91.15 \% \text {. } \\
\text { Chain system, resort area, higher occupancy rate and near the international } \\
\text { airports improve efficiency scores. }\end{array}$ \\
\hline Chen et al. (2010) & DEA & $\begin{array}{l}\text { Taiwan hotels, } \\
\text { 1997-2007 }\end{array}$ & $\begin{array}{l}\text { The chain system, shorter distances to the international airport and } \\
\text { established year can improve cost efficiency. } \\
\text { The tourists' nationalities affect the cost efficiency. }\end{array}$ \\
\hline Assaf et al. (2010) & Meta-frontier & $\begin{array}{l}78 \text { Taiwan hotels, } \\
\text { 2004-2008 }\end{array}$ & $\begin{array}{l}\text { The chain hotels, the large hotels and the international tourist hotels have } \\
\text { higher efficiency scores. }\end{array}$ \\
\hline
\end{tabular}

\section{Methodology and Data}

\subsection{Data Envelopment Analysis}

Development envelopment analysis is a linear programming methodology to measure the efficiency of homogeneous decision-making units (DMUs). Reynolds (2003) points out that DEA focuses managers' attention on specific actions that will improve productivity; therefore, DEA holds great promise for studies aimed at enhancing productivity in hospitality-related operations. The DEA concept is proposed by Farrell (1957) and uses the production frontier to measure the performance. Charnes et al. (1978) construct the first DEA model based on Farrell. They adopt linear programming with multiple inputs and multiple outputs to measure the cost efficiency under the presumptions of constant returns to scale and input orientation. This model is called the CCR model. A fundamental assumption under the CCR model is constant returns to scale (CRS).

We apply the input-oriented CCR model to measure the technical efficiency (TE $\mathrm{CRS}_{\text {) }}$ of ITHs. It means that we want to study how much inputs can be reduced without changing the outputs. Then the cost minimization DEA model under the CRS assumption is applied to compute the cost efficiency $\left(\mathrm{CE}_{\mathrm{CRS}}\right)$ of ITHs. Finally the allocative efficiency under the CRS assumption can be found by the following relation:

$$
A E_{C R S}=C E_{C R S} / T E_{C R S}
$$

The ranges of $\mathrm{CE}, \mathrm{TE}$, and $\mathrm{AE}$ are all between 0 and 1. A DMU has cost, technical, or allocative efficiency when its $\mathrm{CE}, \mathrm{TE}$, or $\mathrm{AE}$ is 1 , respectively. 


\subsection{Truncated Regression}

Past researches often use Tobit regression in the second stage to analyze the impact of environmental variables on cost efficiency. However, Simar and Wilson (2007) indicate that the DEA efficiency estimates are serially correlated in a complicated and unknown manner in the second stage when using Tobit regression; therefore, the results will be inappropriate and invalid. Simar and Wilson (2007) demonstrate that the estimated result of truncated regression is better than Tobit regression. Therefore, we apply the truncated regression in the second stage.

\subsection{Data Sources and Variable Definitions}

The operation of an organization is a procedure to transfer the inputs to the outputs. Mostly, outputs of hotels are measured by their revenues. The revenues of food, beverage and lodging are the main sources and account for about $80 \%$ of the total revenues of the international tourist hotels in Taiwan. Other revenues, for example revenues of swimming, services revenues of laundry, rent and services, etc., are accounted for less than $20 \%$. On the other hand, the inputs of hotels include employees, equipment, and capitals, etc. The salaries of employees represent the human resources of the hotel. The number of rooms and the total floor spaces of catering divisions represent the capital investment of the hotels (Hwang \& Chang, 2003).

Table 2. Definitions of outputs, inputs, input prices and environmental variables

\begin{tabular}{|c|c|}
\hline Variables & Definitions \\
\hline \multicolumn{2}{|l|}{ Outputs } \\
\hline Total revenues of food and beverage & $\begin{array}{l}\text { This includes incomes from sale of foods, snacks, alcohol, beverages in dining room, } \\
\text { coffee room, banquet, and night club (tips are not included), measured in NTD. }\end{array}$ \\
\hline Total revenues of rooms & This includes incomes from lease of rooms (tips are not included), measured in NTD. \\
\hline Other revenues & $\begin{array}{l}\text { This includes incomes other than the two items mentioned above. They include } \\
\text { operating revenues from lease of store space, laundry, swimming pool, ball courts, } \\
\text { barber shop, beauty salons and bookstores, measured in NTD. }\end{array}$ \\
\hline \multicolumn{2}{|l|}{ Inputs } \\
\hline Number of guest rooms & $\begin{array}{l}\text { These include the amount of guest rooms that can be provided for rent from an } \\
\text { international tourist hotel. Accordingly, the unit of measurement is simply "rooms", } \\
\text { without subsequent adjustment for size or quality. }\end{array}$ \\
\hline Number of employees & $\begin{array}{l}\text { Total employees involved in the operation of international tourist hotels, including } \\
\text { medium- and high-ranking executives, guest room and catering staff, cooks, } \\
\text { maintenance crews, and repairmen. }\end{array}$ \\
\hline Total floor spaces of catering divisions & $\begin{array}{l}\text { This includes the total floor spaces used by the operational units of all hotels' catering } \\
\text { facilities, measured in Ping ( } 1 \text { Ping }=3.305785 \text { square meters). }\end{array}$ \\
\hline \multicolumn{2}{|l|}{ Input prices } \\
\hline Average price of room operations & $\begin{array}{l}\text { This refers to the total operating expenses per room, measured in NTD/room. We use } \\
\text { the total revenue of a hotel divided by the number of rooms. }\end{array}$ \\
\hline Average annual employee wage & This includes salary and related expenses per employee, measured in NTD/individual. \\
\hline Average price of F\&B operations & $\begin{array}{l}\text { This refers of catering department expenses per square meter of floor space, measured } \\
\text { in NTD/Ping. }\end{array}$ \\
\hline \multicolumn{2}{|l|}{ Environmental variables } \\
\hline Distance to public transport facilities & $\begin{array}{l}\text { The distance between hotels to the nearest public transport facilities which include } \\
\text { airport, train station, MRT station, freeway exit, bus stop. Distance to MRT station is } \\
\text { expressed by dummy variable, "1" represents less than } 1 \mathrm{~km} \text {. }\end{array}$ \\
\hline Distance to hospital & The distance between hotels to the nearest hospital, measured in kilometer. \\
\hline The number of hospitals & The number of hospitals in each county in Taiwan. \\
\hline The number of medical personnel per ten thousand & Measured in each county in Taiwan \\
\hline Pick-up service & "0" represents no, and "1" represents yes. \\
\hline Type & "0" represents independent management, and "1" represents hotels joining a chain. \\
\hline Year & 1998 is year 1 and 1999 is year 2 , and so on \\
\hline Location & "0" represents metropolitan area, and "1" represents resort area \\
\hline
\end{tabular}


We use the independently pooled panel data which are unbalanced from 1998 to 2009. All the operating variables are collected from the annual Operating Report of International Tourist Hotels in Taiwan published by Taiwan Tourism Bureau. The number of the international hotels varies every year since some of them would fail to reach the criterion set by the government and would be removed from the list. The followings are the numbers of observations from 1998 to 2009: 1998(52), 1999(54), 2000(54), 2001(54), 2002(55), 2003(57), 2004(57), 2005(56), 2006(57), 2007(57), 2008(58), and 2009(56), making 667 observations in total.

The definitions and the descriptive statistics of input variables, output variables, input prices, and environmental variables are described in Tables 2 and 3.

Table 3. Descriptive statistics of outputs, inputs, and input prices

\begin{tabular}{|c|c|c|c|c|c|}
\hline Variables & Units & Mean & SD & Min & $\operatorname{Max}$ \\
\hline \multicolumn{6}{|l|}{ Outputs } \\
\hline Total revenues of food and beverage & $10^{3} \mathrm{NT} \$$ & 275,345 & 274,072 & 3,965 & $1,318,317$ \\
\hline Total revenues of rooms & $10^{3} \mathrm{NT} \$$ & 238,404 & 217,399 & 7,339 & $1,456,306$ \\
\hline Other revenues & $10^{3} \mathrm{NT} \$$ & 98,269 & 141,214 & 0 & $1,415,516$ \\
\hline \multicolumn{6}{|l|}{ Inputs } \\
\hline Number of guest rooms & Number & 72,996 & 43,638 & 3,910 & 246,626 \\
\hline Number of employees & Number & 335 & 229 & 32 & 1,230 \\
\hline Total floor space of catering division & Ping ( 1 Ping $=3.305785$ square meters $)$ & 1,191 & 1,364 & 48 & 16,022 \\
\hline \multicolumn{6}{|l|}{ Input prices } \\
\hline Average price of room operations & NT\$ & 3,060 & 1,336 & 867 & 9,334 \\
\hline Average employee annual wage & NT\$ & 526,014 & 156,231 & 62,239 & 971,509 \\
\hline Average price of $\mathrm{F} \& \mathrm{~B}$ operations & NT\$ & 106,027 & 98,404 & 2,374 & $1,962,222$ \\
\hline
\end{tabular}

Note: The base year for all monetary units is 1998 .

\section{Empirical Results}

\subsection{Operational Efficiency Analysis}

This study adopts input-oriented DEA approach to compute the cost efficiency of international tourist hotels in 1998-2009 by using the Deap 2.1 software kindly provided by Professor Tim Coelli. The average cost efficiency score is $62.41 \%$. It means that hotels in Taiwan can reduce their input costs by $37.59 \%$ without decreasing any output.

Cost efficiency can be divided into technical efficiency and allocative efficiency. Technical efficiency is the ability to maximize the output under given input, while allocative efficiency is the ability to use the inputs and outputs to reach the best proportion given their prices. The trends of the average values of cost efficiency, technical efficiency and allocative efficiency in 1998-1999 are showed in Figure 1. The direction of cost efficiency is very similar to allocative efficiency. That is, the effect of allocative efficiency on cost efficiency is relatively large compared to technical efficiency, and this result is in consistent with the finding in Hu's research in 2009.

We can find 3 obvious recessions in 1999-2000, 2002-2004 and 2006-2007. A 7.3-magnitude earthquake struck Taiwan in 1999 and took 2415 lives. Its epicenter was situated in Nantou which is one of the famous tourist attractions in Taiwan. Some of the hotels there collapsed and had to rebuild due to the earthquake. Therefore, the low cost efficiency in 1999-2000 may reflect the impact of this serious disaster.

The reduction of cost efficiency in 2002-2004 is possibly due to SARS. The first case of SARS appeared in China in 2002 and spread to other countries around the world explosively, and it caused 73 deaths in Taiwan. The international tourist arrivals declined by $24.5 \%$ compared to 2004 . It affected the safety of travelling in Taiwan and the efficiency of ITHs.

The last recession in the Figure 1 between 2006 and 2007 may be influenced by the political instability. In late 
2006, demonstration campaigns and incidents were held to pressure the President Shui-bian Chen to resign, resulting in the massive political and social turmoil in Taiwan. The occupancy rate of ITHs is $47.43 \%$ only in 2007 , and it has been the lowest figure in the recent twelve years.

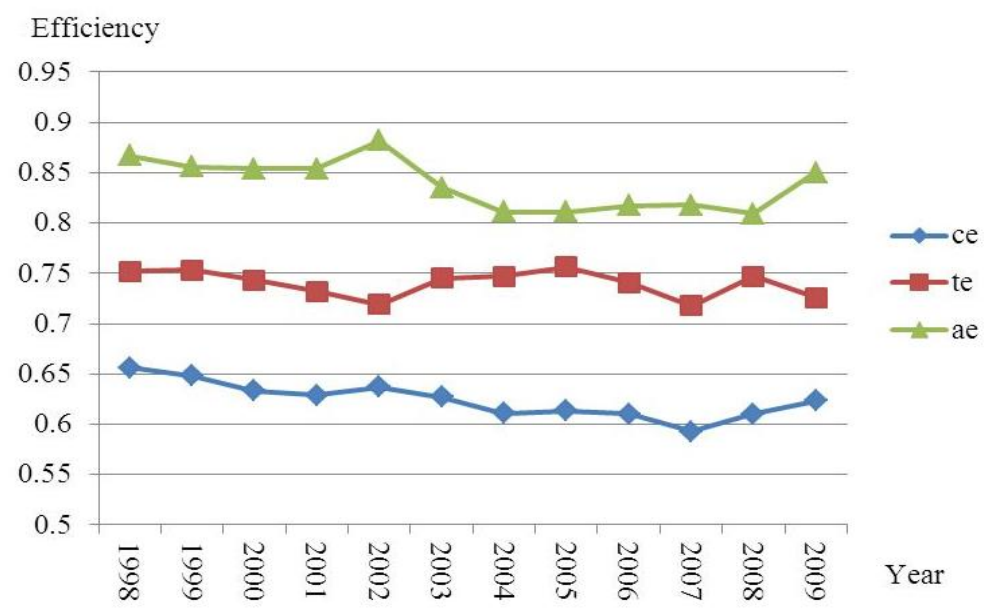

Figure 1. Average efficiency scores of international tourist hotels in Taiwan during 1998-2009

Table 4. Top 5 cost-efficient and cost-inefficient hotels in 1998-2009

\begin{tabular}{|c|c|c|c|c|}
\hline CE Ranking & Taiwan ITH Name & $\mathrm{CE}$ & $\mathrm{TE}$ & $\mathrm{AE}$ \\
\hline \multicolumn{5}{|c|}{ Top 5 cost-efficient hotels } \\
\hline 1 & Lalu hotel & 1.00 & 1.00 & 1.00 \\
\hline 2 & Grand Formosa Regent Taipei & 0.99 & 1.00 & 0.99 \\
\hline 3 & Grand Hyatt Taipei & 0.98 & 1.00 & 0.98 \\
\hline 4 & Far Eastern Plaza Hotel Taipei & 0.96 & 0.99 & 0.97 \\
\hline 5 & The Westin Hotel & 0.92 & 0.98 & 0.93 \\
\hline \multicolumn{5}{|c|}{ Top 5 cost-inefficient hotels } \\
\hline 65 & The Hibiscus Resorts & 0.34 & 0.40 & 0.87 \\
\hline 66 & Taipei Fortuna Hotel & 0.34 & 0.40 & 0.83 \\
\hline 67 & Hotel Kingdom & 0.33 & 0.46 & 0.74 \\
\hline 68 & Jen Dow International Hotel & 0.30 & 0.36 & 0.82 \\
\hline 69 & Park Hotel & 0.27 & 0.35 & 0.77 \\
\hline \multicolumn{2}{|c|}{ Average of all hotels } & 0.62 & 0.74 & 0.84 \\
\hline
\end{tabular}

Table 4 shows the average efficiency, technical efficiency, and allocative efficiency of top 5 cost-efficient and cost-inefficient hotels during 1998-2008. The cost efficiency score of Lalu hotel located in Nantou is the highest, which is equal to 1 . The efficiency of Park hotel located in Taichung is $26.88 \%$ and which is the poorest among all the ITHs. In Table 4, we also can find that the allocative efficiency scores of top 5 cost-inefficient hotels are similar to the overall average, while their technical efficiency is much lower than the overall average score and the top 5 efficient hotels. It indicates that technical inefficiency is the main factor of cost inefficiency. Namely, these inefficiency hotels may have too many unneeded resources or be inefficient in execution. We suggest hotel managers to focus on utilizing resources effectively to create maximum outputs by making appropriate marketing or management strategies.

\subsection{Result of Truncated Regression}

We use two models to test the effect of transportation cost (model A) and medical services (model B) on the 
efficiency of hotels by truncated regression. Six environment variables included in model A are: distance to the international airport (DAIR), distance to bus stop (DBUS), distance to freeway exit (DFW), distance to MRT exit (DMRT; 0= less than $1 \mathrm{KM}, 1=$ further than $1 \mathrm{KM}$ ), distance to train station (DTRAIN) and pick-up service (SER; $1=$ yes, $0=$ no). Three environment variables included in model B are: distance to hospital (DHOS), the number of hospitals (NHOS) and the number of medical personnel per ten thousand (PEO). Three environment variables used in both models are: type of operation (TYPE; $1=$ chain, $0=$ independent), established years (YEAR) and type of location (LOC; $1=$ resort area, $0=$ metropolitan area). The cost efficiency scores are dependent variables in both models.

Table 5. Estimated results of truncated regression on cost efficiency

\begin{tabular}{|c|c|c|}
\hline Independent variables & Model A & Model B \\
\hline & Cost efficiency & Cost efficiency \\
\hline \multirow[t]{2}{*}{ Constant } & $0.5712^{* * *}$ & $0.5003^{* * *}$ \\
\hline & $(<.001)$ & $(<.001)$ \\
\hline \multirow[t]{2}{*}{ DAIR } & $-0.0004^{* *}$ & \\
\hline & $(0.0325)$ & \\
\hline \multirow[t]{2}{*}{ DBUS } & $5.3 \mathrm{E}-05^{* * *}$ & \\
\hline & $(0.0079)$ & \\
\hline \multirow[t]{2}{*}{ DFW } & $0.0004 *$ & \\
\hline & $(0.0526)$ & \\
\hline \multirow[t]{2}{*}{ DMRT } & $-0.1473^{* * *}$ & \\
\hline & $(<.001)$ & \\
\hline \multirow[t]{2}{*}{ DTRAIN } & 0.0015 & \\
\hline & $(0.2227)$ & \\
\hline \multirow[t]{2}{*}{ SER } & $0.0766^{* * *}$ & \\
\hline & $(0.0020)$ & \\
\hline \multirow[t]{2}{*}{ DHOS } & & $-0.0040^{* * *}$ \\
\hline & & $(0.0011)$ \\
\hline \multirow[t]{2}{*}{ NHOS } & & $5.7 \mathrm{E}-05^{* * *}$ \\
\hline & & $(<.001)$ \\
\hline \multirow[t]{2}{*}{ PEO } & & $-6.6 \mathrm{E}-05$ \\
\hline & & $(0.4761)$ \\
\hline \multirow[t]{2}{*}{ TYPE } & $0.1338^{* * *}$ & $0.1112^{* * * *}$ \\
\hline & $(<.001)$ & $(<.001)$ \\
\hline \multirow[t]{2}{*}{ YEAR } & $-0.0015^{* * *}$ & $-0.0032^{* * * *}$ \\
\hline & $(0.0045)$ & $(<.001)$ \\
\hline \multirow[t]{2}{*}{ LOC } & -0.0084 & $0.1370^{* * *}$ \\
\hline & $(0.8321)$ & $(<.001)$ \\
\hline
\end{tabular}

****,$*$, and ${ }^{*}$ represent significance at the $1 \%, 5 \%$, and $10 \%$ levels.

The number in the parenthesis () is the P-value.

The estimated results of two truncated regressions are listed in Table 5. As for the impact of travel convenience, distance to the international airport and the distance to MRT station have a significantly negative impact on the efficiency, while the distance to the freeway exit, distance to bus station, and pick-up service have significantly positive impacts on the cost efficiency. This means that a hotel close to the airport and MRT station, far away 
from the bus station and freeway exit, or with pick-up service has significantly higher cost efficiency. The results may be driven by the preference of travelers. According to the statistics from Taiwan Tourism Bureau, about $99 \%$ of international tourists visited Taiwan by taking airplanes, and about $60 \%$ of them lodged in Taipei in 2009 . Taipei is the most developed region with MRT system in Taiwan. It implies that hotels near the airport and MRT stations or with pick-up services are more convenient to be accessed by international tourists and can receive higher cost efficiency scores.

As for the impact of medical services, the coefficient for the distance to hospital is significantly negative, and the coefficient for the number of hospitals is significantly positive. In other words, the shorter distance between hotels and hospitals, or there are more hospitals available in a region, the higher cost efficiencies of these hotels would have.

The coefficients of the type of operation and the established year are significant in both models. The type of operation being chain-operated and latter established year would increase the cost efficiency of ITHs. The type of location shows a significantly positive effect on efficiency in model B, suggesting that hotels located in resort areas has better cost efficiency.

\section{Conclusion}

With the rapid growth of economy and more attention given to recreation, tourism has become an important industry in many countries, among which Taiwan is of no exception. The number of hotels has increased dramatically since 1985, and the hotel industry is becoming oversupplied. With the growing competition in the sector, the efficiency of hotel management has become a key factor in gaining profit. Although plenty of studies have analyzed the international tourist hotel efficiency in Taiwan, we try to take a more rigorous approach to explain the cost efficiency in a different way. We apply input-oriented cost DEA to compute the cost efficiency of international tourist hotels and adopt a truncated model to explain the cost efficiency by introducing variables of traffic convenience and medical services.

The cost efficiency of international tourist hotels in Taiwan from 1998 to 2009 is $62.41 \%$. We can find that infectious diseases, natural disasters and unstable politics are reasons of the declination of average cost efficiency, and most of these factors are unavoidable. Therefore, the hotel managers are suggested to work out strategies previously and invest appropriately to avoid being bankrupted in the recession of the tourism industry. The government should design an effective response mechanism for emergencies such as infectious diseases and natural disasters to minimize any loss and regain shortly the international tourists' confidence in having a trip in Taiwan. For those cost-inefficient hotels, technical inefficiency due to their idle resources is possibly the main cause. Thus, we suggest those hotel managers to maximize the outputs with given inputs by making better management and promotion strategies.

In the result of truncated regression, we point that the hotels near international airports, MRT stations or other pick-up services may have higher cost efficiency. This can be shown that the hotels near airports and MRT stations are easier to be accessed by international tourists. Based on the result of the truncated regression, we suggest that hotels near international airports, MRT stations, and with pick-up services shall gain advantages in advertisement and on the websites to attract more tourists and achieve a better performance. For new investors in the hotel industry, they should regard the distance factor, such as distance to an international airport and an MRT station, as an important factor in selecting hotel location. The government also needs to be dedicated to the transportation development, especially to the means of transportation between hotels, airports, and scenic spots for promoting the coordination between the tourist and hotel industries.

As for the medical services, the shorter distance to a hospital or more hospitals in a region, the higher cost efficiency of the hotel will have. It can be regarded also that hotels with more medical resources nearby are more efficient. Medical tourism is a hot issue in recent years. After allowing the residents in mainland China to visit Taiwan, medical tourism has been regarded an enormous commercial opportunity to be exploited. To follow this trend, we suggest the hotel managers to cooperate with the traveling agencies and the hospitals for effectively introducing a medical travel itinerary. It is also available to integrate health-care programs into the hotel services to satisfy the customers' needs of medical treatments. Introducing the programs, services and other information about medical tourism through hotel websites to attract international travelers is also an effective way to be used. For the government, it is suggested to improve the medical standard in Taiwan and to introduce a better medical environment when promoting the tourist business. With the improvement of medical environment, the number of international tourists shall grow, and the hotels in Taiwan shall achieve a better performance.

The results of other environment variables are similar to the previous studies. The hotels operating in chain system may have higher cost efficiency scores than those of the hotels operating independently. Hotels with 
shorter operating years generally receive higher efficiency scores. We find that most inefficient hotels are depending on independent management and with longer operating years. We suggest that these cost-inefficient hotels are in need of introducing a modernized management and meanwhile finding their own market positions. The Lalu hotel which operates independently is a successful example for these hotels. The Lalu hotel positions itself as a top-end resort hotel, having its architecture designed in natural beauty and providing its customers with high-class and customized services. It is the most famous and cost-efficiency international tourist hotel in Taiwan.

In future research, we may add the preferences of tourists with different nationalities or the main purposes of trips as a variable to the model to analyze the effects of travel convenience and medical services on the hotel selection. In addition, adding hotels in other Asian countries for observation will help us compare their differences.

\section{Acknowledgements}

The authors thank two anonymous referees of this journal of the valuable comments. Financial support from Taiwan's Ministry of Science and Technology is gratefully acknowledged (NSC100-2410-H-009-051).

\section{References}

Akama, J. S., \& Kieti, D. M. (2003). Measuring tourist satisfaction with Kenya's wildlife safari: a case study of Tsavo West National Park. Tourism Management, 24(1), 73-81. http://dx.doi.org/10.1016/S0261-5177(02)00044-4

Anderson, R. I., Fish, M., Xia, Y., \& Michello, F. (1999). Measuring efficiency in the hotel industry: a stochastic frontier approach. International Journal of Hospitality Management, 18(1), 45-57. http://dx.doi.org/10.1016/S0278-4319(98)00046-2

Assaf, A., Barros, C. P., \& Josiassen, A. (2010). Hotel efficiency: A bootstrapped metafrontier approach. International Journal of Hospitality Management, $29, \quad 468-475$. http://dx.doi.org/10.1016/j.ijhm.2009.10.020

Barros, C. P., \& Dieke, P. U. C. (2008). Technical efficiency of African hotels. International Journal of Hospitality Management, 27(3), 438-447. http://dx.doi.org/10.1016/j.ijhm.2007.11.004

Barros, C. P., \& Mascarenhas, M. J. (2005). Technical and allocative efficiency in a chain of small hotels. Hospitality Management, 24(3), 415-436. http://dx.doi.org/10.1016/j.ijhm.2004.08.007

Batabyal, D., \& Ghosh, B. K. (2012). A study of foreign tourist arrivals to India: A descriptive study through empirical evidences. South Asian Journal of Tourism and Heritage, 5(1), 91-102.

Brown, W. G., \& Nawas, F. (1973). Impact of aggregation on the estimation of outdoor recreation demand functions. American Journal of Agricultural Economics, 55(2), 246-249.

Carter, S. (1998). Tourists' and travellers' social construction of Africa and Asia as risky locations. Tourism Management, 19(4), 349-358. http://dx.doi.org/10.1016/S0261-5177(98)00032-6

Charnes, A. W., Cooper, W. W., \& Rhodes, E. (1978). Measuring the efficiency of decision making units. European Journal of Operational Research, 2(6), 429-444. http://dx.doi.org/10.1016/0377-2217(78)90138-8

Chen, C. F. (2007). Applying the stochastic frontier approach to measure hotel managerial efficiency in Taiwan. Tourism Management, 28(3), 696-702. http://dx.doi.org/10.1016/j.tourman.2006.04.023

Chen, C. T., Hu, J. L., \& Liao, J. J. (2010). Tourists' nationalities and the cost efficiency of international tourist hotels in Taiwan. African Journal of Business Management, 4(16), 3440-3446.

Chou, C. E., Li, C. Y., \& Tsai, Y. P. (2011). Taiwan Tourism Satellite Account 2009. Taipei: Taiwan Tourism Bureau.

Chou, T. Y., Hsu, C. L., \& Chen, M. C. (2008). A fuzzy multi-criteria decision model for international tourist hotels location selection. International Journal of Hospitality Management, 27(2), 293-301. http://dx.doi.org/10.1016/j.ijhm.2007.07.29

Earnhahrt, D. (2004). Time is money: improved valuation of time and transportation costs. Environmental and Resource Economics, 29(2), 159-190. http://dx.doi.org/10.1023/B:EARE.0000044604.77782.6b

Farrell, M. J. (1957). The measurement of productive efficiency. Journal of the Royal Statistical Society, Series A, 120(3), 253-290. http://dx.doi.org/10.2307/2343100 
Gauci, A., Gerosa, V., \& Mwalwanda, C. (2002). Tourism in Africa and the multilateral trading system: challenges and opportunities. Background Paper for the Economic Commission for Africa, Addis Ababa.

Honma, S., \& Hu, J. L. (2012). Analyzing Japanese hotel efficiency: A DEA application. Tourism and Hospitality Research, 12(3), 155-167. http://dx.doi.org/10.1177/1467358412470558

Hu, J. L., Chiu, C. N., Shieh, H. S., \& Huang, C. H. (2010). A stochastic cost efficiency analysis of international tourist hotels in Taiwan. International Journal of Hospitality Management, 29(1), 99-107. http://dx.doi.org/10.1016/j.ijhm.2009.06.005

Hu, J. L., Shieh, H. S., Huang, C. H., \& Chiu, C. N. (2009). Cost efficiency of international tourist hotels in Taiwan: A data envelopment analysis application. Asia Pacific Journal of Tourism Research, 14(4), 371-384. http://dx.doi.org/10.1080/10941660903310060

Hwang, S. N., \& Chang, T. Y. (2003). Using data envelopment analysis to measure hotel managerial efficiency $\begin{array}{llll}\text { change in Taiwan. Tourism } & \text { Management, }\end{array}$ http://dx.doi.org/10.1016/S0261-5177(02)00112-7

Khadaroo, J., \& Seetanah, B. (2008). The role of transport infrastructure in international tourism development: A gravity model approach. Tourism Management, 29(5), 831-840. http://dx.doi.org/10.1016/j.tourman.2007.09.005

Lepp, A., \& Gibson, H. (2003). Tourist roles, perceived risk and international tourism. Annals of Tourism Research, 30(3), 606-624. http://dx.doi.org/10.1016/S0160-7383(03)00024-0

Loomis, J., Yorizane, S., \& Larson, D. (2000). Testing significance of multi-destination and multi-purpose trip effects in a travel cost method demand model for whale watching trips. Agricultural and Resource Economics Review, 29(2), 183-191.

Prideaux, B. (2000). The role of the transport system in destination development. Tourism Management, 21(1), 53-63. http://dx.doi.org/10.1016/S0261-5177(99)00079-5

Reynolds, D. (2003). Hospitality productivity assessment using data envelopment analysis. Cornell Hotel and Restaurant Administration Quarterly, 44(2), 130-138. http://dx.doi.org/10.1016/S0010-8804(03)90026-7

Saleh, F., \& Ryan, C. (1992). Client perceptions of hotels: A multi-attribute approach. Tourism Management, 13(2), 163-168. http://dx.doi.org/10.1016/0261-5177(92)90058-F

Shieh, H. S., Hu, J. L., \& Gao, L. Y. (2014). Tourist preferences and cost efficiency of international tourist hotels in Taiwan. International Journal of Marketing Studies, 6(3), 35-48. http://dx.doi.org/10.5539/ijms.v6n3p35

Simar, L., \& Wilson, P. W. (2007). Estimation and inference in two-stage, semi-parametric models of production process. Journal of Econometrics, 136(1), 31-41. http://dx.doi.org/10.1016/j.jeconom.2005.07.009

Taiwan Tourism Bureau (1999-2010). Operating Report of International Tourist Hotels in Taiwan. Taipei.

Tsaur, S. H. (2001). The operating efficiency of international tourist hotels in Taiwan. Asia Pacific Journal of Tourism Research, 6(1), 73-81. http://dx.doi.org/ 10.1080/10941660108722090

Tsaur, S. H., Tzeng, G. H. \& Wang, K. C. (1997). Evaluating tourist risks from fuzzy perspectives. Annals of Tourism Research, 24(4), 796-812. http://dx.doi.org/10.1016/S0160-7383(97)00059-5

World Health Organization (WHO). (2011). International travel and health. Switzerland.

Yang, C. H., Lin, H. L., \& Han, C. C. (2010). Analysis of international tourist arrivals in China: The role of $\begin{array}{lllll}\text { World Heritage } & \text { Sites. }\end{array}$ http://dx.doi.org/10.1016/j.tourman.2009.08.008

\section{Copyrights}

Copyright for this article is retained by the author(s), with first publication rights granted to the journal.

This is an open-access article distributed under the terms and conditions of the Creative Commons Attribution license (http://creativecommons.org/licenses/by/3.0/). 